\title{
APRIL IN PARIS
}

Theatricality, Modernism, and Politics

at the 1925 Art Deco Expo 
This page intentionally left blank 


\title{
April in Paris
}

Theatricality, Modernism, and Politics at the 1925 Art Deco Expo

\author{
IRENA R. MAKARYK
}


(C) University of Toronto Press 2018

Toronto Buffalo London

utorontopress.com

Printed in the U.S.A.

ISBN 978-1-4875-0372-7 (cloth)

$\otimes$ Printed on acid-free paper.

\section{Library and Archives Canada Cataloguing in Publication}

Makaryk, Irena R. (Irena Rima), 1951-, author

April in Paris : theatricality, modernism, and politics at the 1925 Art Deco Expo/ Irena R. Makaryk.

Includes bibliographical references and index. ISBN 978-1-4875-0372-7 (hardcover)

1. Exposition internationale des arts décoratifs et industriels modernes (1925: Paris, France). 2. Exhibitions - Political aspects - France - Paris - History 20th century. 3. Exhibitions - France - Paris - History - 20th century.

4. Theater - Political aspects. 5. Aesthetics, Modern-20th century. I. Title. T805.1925.L1M35 $2018 \quad 907.4^{\prime} 4436 \quad$ C2018-900947-0

This book has been published with the help of a grant from the Federation for the Humanities and Social Sciences, through the Awards to Scholarly Publications Program, using funds provided by the Social Sciences and Humanities Research Council of Canada.

University of Toronto Press acknowledges the financial assistance to its publishing program of the Canada Council for the Arts and the Ontario Arts Council, an agency of the Government of Ontario.

Canada Council for the Arts
Conseil des Arts du Canada 
For Natalia, Larissa, and Yaroslaw 
This page intentionally left blank 
Paris n'est pas une ville, c'est un Monde.

(attributed to Charles V) 
This page intentionally left blank 